Although it is not shown in these results, since no accurate estimate could be made of leucocytes containing more than 20 starch particles, the leucocytes were most active in the presence of mixed blood serum. This was the only treatment where the number of starch particles was visibly diminished in the fluid surrounding the loncocytes.

The results of both series of experiments lead to the conclusion that there is some factor in the uterine secretion under the influence of progesterone which inhibits the phagocytic activity of leucocytes in vivo and in vitro. Chemical analyses of the uterine washings of the rabbit under different hormonal conditions have shown that the major difference in composition lies in the presence of an acid-soluble seromucoid component under the influence of progesterone ${ }^{7}$. The present experiments should provide a basis for isolating the component or components resonsible for inhibiting phagocytosis in the uterus.

We thank Dr. M. J. Wolf, U.S. Department of Agriculture, Peoria, Illinois, for a gift of starch from Amaranthus cruentus.

\section{Jean KillingBeck}

University of Nottingham, G. E. Lamming

Sutton Bonington,

Loughborough.

'Broome, A. W. J., Lamming, G. E., and Smith, Wendy, J. Endocrinol., 19, 274 (1959).

a Broome, A. W. J., Winter, A. J., McNutt, S. H., and Casida, L. E., Amer. J. Vet. Res., i2, 675 (1960).

-Hawk, H. W., Turner, G. D., and Sykes, J. F., Amer, J. Vet. Res., 21 $644(1060)$.

'Winter, A. J., Broome, A. W. J., McNutt, S. H., and Casida, L. E., Amer. $J$. Vet. Res., 21,668 (1960).

'Heap, R. B. Robinson, D. W., and Lamming, G. M., J. Endocrinol., 28,

- Killingbeck, J. (unpublished results)

'Heap, R. B., and Lamming, G. E., J, Endocrinol,, 20, 23 (1960).

\section{MISCELLANEOUS}

\section{Blotting Procedure for Adequate Drying of Isolated Tissue Preparatory to Chemical Analyses}

Is performing chemical determinations on isolated tissues, one is faced with the problem of adequate removal of superficial fluid which adheres to the tissue. This fluid is usually removed by blotting with 'ion-free' filter paper. A search of the literature reveals little information concerning a suitable blotting procedure, so one is described here which ensures adequate removal of superficial but not intercellular fluid.

Forty-one male Wistar rats (205-345 g) were killed by decapitation. The hearts were removed and placed in a beaker containing Krebs-Ringer bicarbonate solution which was gassed with 95 per cent oxygen-5 per cent carbon dioxide and kept at room temperature. After about $2 \mathrm{~min}$, the hearts were transferred to a Petri dish containing gassed Krebs-Ringer bicarbonate solution. The auricles were carefully removed and freed of adhering tissue. They were then transferred to 'ion-free' filtor paper (Whatman No. 42), turned once, placed on small pans of aluminium foil and weighed. They were then blotted gently between the fingertips 5 times and rewoighed. A new filter paper was used for each five blottings. This process was repeated until a total of 50 blottings had been performed. The time for the entire blotting and weighing procedure was 19-22 min. The results from ten rats wore averaged and plotted. From Fig. 1 it can be seen that up to 20 blottings the loss of water does not follow an exponential curve. Aftor 20 blottings, the loss of water is exponential and presumably due mainly to evaporation of intorcellular fluid rather than blotting of superficial fluid. To test this assumption, a rat auricle was blotted 20 times and weighod. It was then left on the balance and the weight recorded every

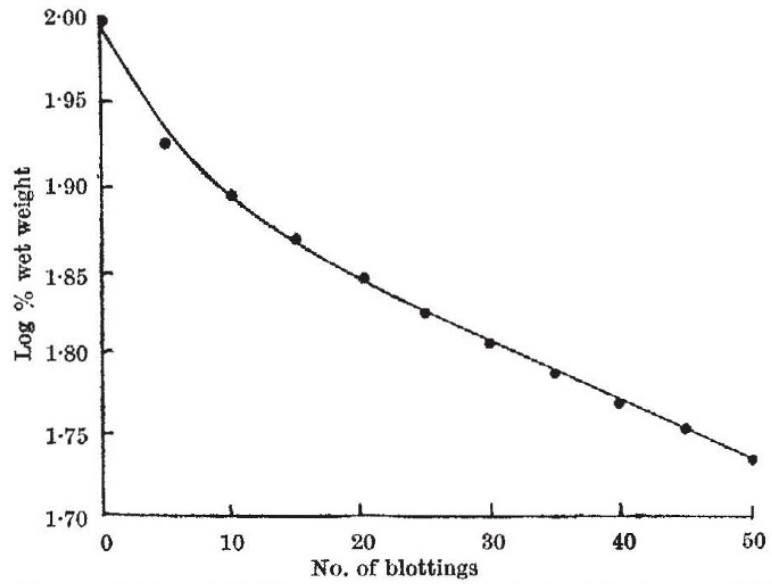

Fig. 1. Effect of blotting on wet weight of rat atria (mean of 10

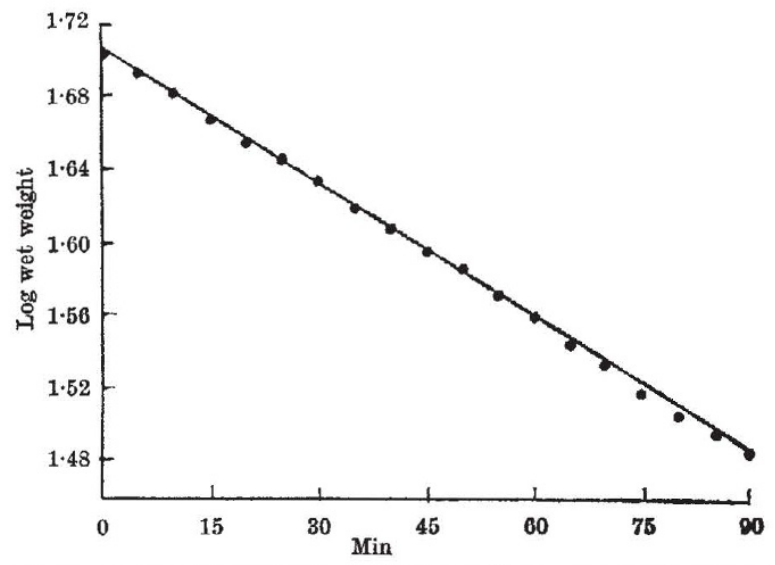

Fig. 2. Change in wet weight of rat atria with time due to evaporation of water

5 min for 1.5 h. From Fig. 2 it can be seen that the loss of water by evaporation is exponential.

In order to test this assumption further, auricles were placed on filter paper, turned once, blotted either 10, 20 or 30 times and weighed. The time required for blotting and weighing was kept constant and at a minimum to reduce loss of water by evaporation. The blotting and weighing procedures took 2,3 and $3.5 \mathrm{~min}$ respectively. The auricles were then dried to constant weight at $110^{\circ} \mathrm{C}$ for at least $24 \mathrm{~h}$ and re-weighed. The percentage of water was calculatod and the results are given in Table 1.

Table 1. INFLUENCE OF BLOTTING ON WATER CONTENT OF RAT AURTOMES No. of No. of Mean wet weight Mean dry weight Percentage blottings atria of atria of atria

$\begin{array}{ccccc}\text { blottings } & \text { atria } & \begin{array}{c}\text { of atria } \\ (\mathrm{mg})\end{array} & \begin{array}{c}\text { of atria } \\ \text { (mg) }\end{array} & \text { of water } \\ 10 & 10 & 40 \cdot 83 & 7 \cdot 86 & 80 \cdot 7 \pm 1 \cdot 19 * \\ 20 & 10 & 45 \cdot 84 & 10 \cdot 17 & 77 \cdot 8 \pm 1 \cdot 02 \\ 30 & 10 & 42 \cdot 72 & 9 \cdot 55 & 77 \cdot 6 \pm 0.72\end{array}$

A significant difference was found between the percentage water at 10 and 20 blottings $(P<0.001, t$ test $)$. No significant difference was found between the percentage water at 20 and 30 blottings $(P>0.5 t$ test). It was noted that, after 20 blottings, the tissue no longer left a water spot on the filter papor.

This investigation was supported by a post-doctoral fellowship, $H-12,112-C 1$, from the National Heart Institute, U.S. Public Hoalth Service.

Dopartment of Pharmacology, Raymond R. Paradise *

School of Modicine,

University of Southern California, Los Angeles.

- Present address: Departments of Anesthesiology and Pharmacology, University of Indiana, Indianapolis. 